\title{
A General Method for Synthesis of Isomaleimide Derivatives
}

\author{
Sudershan R. Gondi * \\ Department of Chemistry, Southern Methodist University, 3215 Daniel Avenue, Dallas, \\ Texas 75275-0314, USA
}

\begin{abstract}
A mild and efficient method for the synthesis of isoimide by a simple reaction of 1-(3dimethylaminopropyl)-3-ethylcarbodiimide hydrochloride (EDC) with various kinds of maleimicacid, succimicacid, pthaleimicacid in dichloromethane at room temperature is described.
\end{abstract}

Key words: Imidic acid, Imide, isoimide, Isomaleimide, EDC, dehydrating agent

Introduction: Imidic acid derivatives on dehydration under different conditions give corresponding imides and isoimides. A large number of applications of imides are known and plenty of methods to design them are well established. ${ }^{1,2}$ In comparison with imide, the isoimide chemistry is less explored and only limited isoimide chemistry is known. In 1955 Tsou et al reported the first isomaleimide synthesis using trifluoracetic anhydride as a dehydrating agent, recently isoimide have found applications in preparation of surfmers, ${ }^{3}$ novel polyimides, ${ }^{4}$ novel polyisoimides, ${ }^{5}$ pharmaceuticals,${ }^{6}$ spiro b-lactams,${ }^{7}$ resins,${ }^{8}$ polyhydrazides,${ }^{9}$ herbicidal antidotes, ${ }^{10}$ membranes, ${ }^{11}$ adhesives, ${ }^{12}$ diagnosis and cancer treatment and in vivo photodynamic therapy. ${ }^{13}$ Isoimides are useful in the detection and measurement of biological materials such as bacteria, enzymes and hormones. ${ }^{14}$ Presently isomaleimides have been synthesized from the corresponding maleamic acids by using (i) $\mathrm{COCl} 2 / \mathrm{Et} 3 \mathrm{~N},{ }^{15}$ (ii) $\mathrm{DCC},{ }^{11}$ (iii) Ac2O/NaOAc, ${ }^{16}$ (iv) 
$\mathrm{CH} 3 \mathrm{COCl} / \mathrm{Et} 3 \mathrm{~N},{ }^{7}$ (v) $\mathrm{EtOCOCl} / \mathrm{Et} 3 \mathrm{~N},{ }^{7}$ (vi) $(\mathrm{CF} 3 \mathrm{CO}) 2 \mathrm{O} / \mathrm{Et}_{3} \mathrm{~N},{ }^{17}$ (vii) ketenes ${ }^{18}$ and (viii) 2chloro-1,3-dimethylimidazolinium chloride ${ }^{19}$ and cynuric chloride. ${ }^{20}$

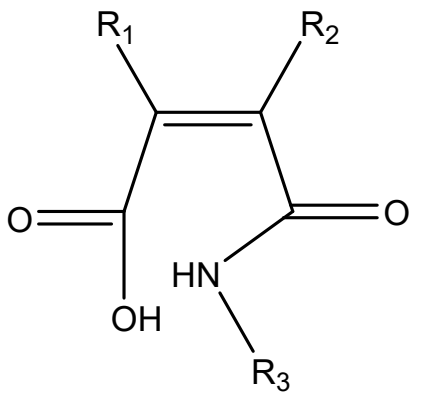

$$
\underset{\mathrm{RT}, 10-15 \mathrm{~min},}{\mathrm{EDCI} / \mathrm{CH}_{2} \mathrm{Cl}_{2}}
$$
$90-98 \%$

$$
\mathrm{R}_{1}=\mathrm{R}_{2}=\mathrm{H}, \mathrm{C}_{6} \mathrm{H}_{4}, \mathrm{R}_{3}=\mathrm{CH}_{3}, \mathrm{C}_{2} \mathrm{H}_{5}, \mathrm{CH}_{2} \mathrm{O}, \mathrm{C}_{2} \mathrm{H}_{5} \mathrm{O}, \mathrm{C}_{3} \mathrm{H}_{7} \mathrm{O}
$$

However, previously reported methods require severe conditions, toxic reagents solvents and suffer from side reactions and products are obtained low yields. Thus, the reaction condition needs to be as mild as possible. Consequently, there is a need to develop alternative methods for the synthesis of isomalemide from readily available reagents and in efficient manner.

1-(3-dimethylaminopropyl)-3-ethylcarbodiimide hydrochloride (EDC) is widely popular as a coupling agent in synthetic organic chemistry. Due to the easy workup of EDC, high yields and lower reaction time, results in pure products without column chromatography. Herein, we wish to report a simple and convenient method for the synthesis of isomalemide through dehydration of maleamicacid, succinamicacid in the presence of EDC in dichloromethane solvent at room temperature.

In our research group we have been using bismaleamicacid to synthesize the bismaleimide as potential precursors for the synthesis of polymer bond reaction with Bovarian Serum Albumen for bioconjugate studies of peptides polymers ${ }^{21}$. In order to obtain the bismaleimide we are 
exploring various kind of dehydrating agents, in one of the reactions we treated the bis maleimidic acid2 (1a) with EDC in dichloromethane, to our surprise the reaction mixture is very clear within 10-15 minutes from suspension, and we got the regioselective bis isomaleimide ${ }^{22}$, 1b in quantitative yields. To test this methodology, we treated the 1a with EDC in various solvents. In DMF, the reaction is time is 20 minutes and yield are less and required purification. We repeat the reaction in THF, the reaction is sluggish and went for 6 hours. In one reaction, HOBT is used as acid activator, to our surprise complex product is formed, when we repeat the reaction with DCC in dichloromethane, it took 6 hours and obtained $63 \%$ yield only after column chromatography to separate the substituted urea.

In a typical procedure, suspend $1.0 \mathrm{~g}(2.9 \mathrm{mmol}, 1.0 \mathrm{eq})$ of dimaleimideacid222 (3a) in dichloromethane (15 mL), 1-(3-dimethylaminopropyl)-3-ethylcarbodiimide hydrochloride (EDC, $1.22 \mathrm{~g}, 6.4 \mathrm{mmol}, 2.2 \mathrm{eq}$ ) were added and the resulting mixture was stirred at room temperature and stirred for 10-15 minutes to form clear solution. The reaction mixture was then poured into $10 \%$ aqueous sodium bicarbonate solution $(25 \mathrm{~mL})$ and stirred for $10 \mathrm{~min}$. The aqueous layer was extracted with dichloromethane $(2 \times 25 \mathrm{~mL})$, and the combined organic layers were washed with $10 \%$ aqueous sodium bicarbonate solution $(25 \mathrm{~mL})$, water $(25 \mathrm{~mL})$, and brine $(25 \mathrm{~mL})$. The organic layer was then dried over anhydrous $\mathrm{MgSO}_{4}$ and filtered. Removal of volatiles using a rotary evaporator gave a product ${ }^{23}, \mathbf{3 b}$ as white solid $(0.87 \mathrm{~g}, 97 \%)$. 
Page 4 of 9

Synthesize of Bis-isomaleimide with EDC in DCM at room temperature

\begin{tabular}{|l|l|l|l|}
\hline Yields \\
\hline
\end{tabular}


Page 5 of 9

\begin{tabular}{|l|l|l|l|}
\hline & $91 \%$ \\
\hline
\end{tabular}

To generalize this methodology, we treated several maleamic acid derivative with EDC furnished exclusively the corresponding desired $\mathrm{N}$-arylisomaleimides ${ }^{24-26}$ in $90-98 \%$ yields. The phthalanilic acid also gave the corresponding N-alkyl-iso phthalimide in $90-95 \%$ yields indicating that the present dehydration condition works equally well in prolong period. Generally, the isomaleimide with a chiral central next to imine-nitrogen, during the reaction chirality's remains intact. The product $1 \mathrm{~b}-9 \mathrm{~b}$ structures were established from the characteristic lactone carbonyl and imine double bond stretching frequencies in infra-red spectra, presence of two doublet peaks for the vinylic protons in ${ }^{1} \mathrm{H}$ NMR and ${ }^{13} \mathrm{C}$ NMR spectral data.

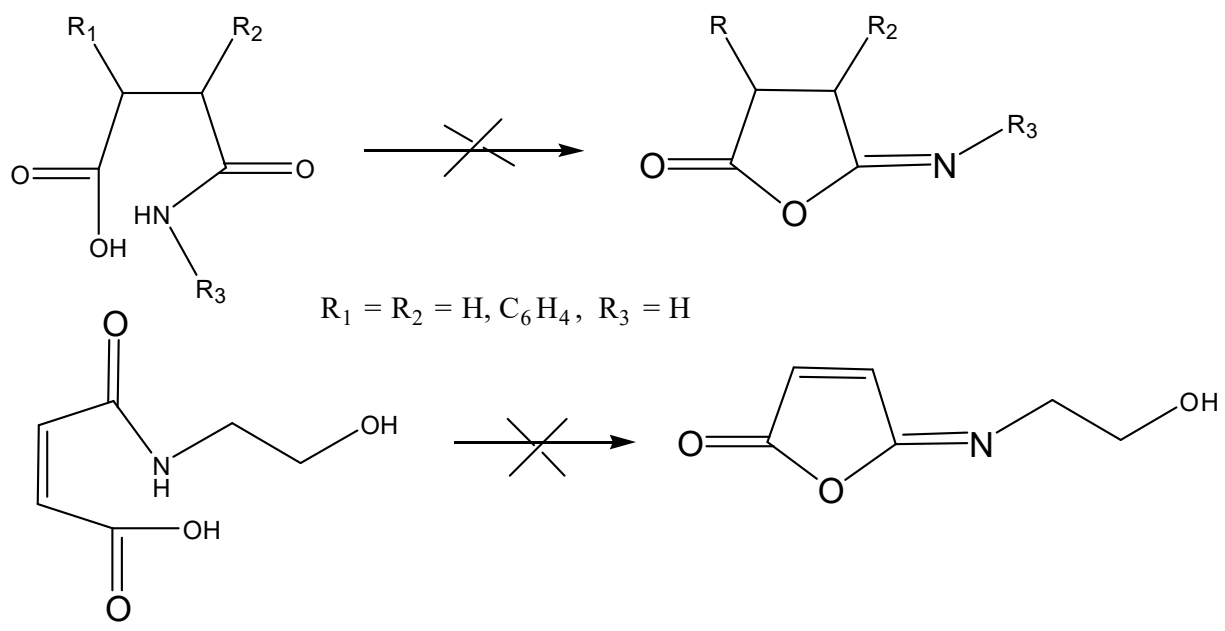


However unsubstituted maleamic acid, succciniamic acid and phthaleimic acid under similar condition does not yields the product even prolong the reaction time. The free hydroxyl group in starting material is interfering during reaction ending with complex product.

In conclusion the present work provides a new method for the preparation of isomaleimide through a 1-(3-dimethylaminopropyl)-3-ethylcarbodiimide hydrochloride (EDC) as a dehydrating agent The notable advantage of this methodology are mild condition, general applicability, lower reaction time, no column chromatography purification, high yields and no polluting reagents to be used. We believe this will serve as a useful addition to modern synthetic methods.

\section{ACKNOWLEDGMENTS}

S.R.G is thankful to Prof. Brent Sumerlin, SMU for supporting in the form of post-doctoral associate fellowship during January-2006 to December-2007 and allowing to work on this work.

\section{References and notes}

1. (a) Tsou, K. C.; Barnett, R. J.; Seligman, A. M. J. Am. Chem.Soc. 1955, 77, 4613. (b) Sauers, C. K.; Cotter, R. J. J. Org.Chem. 1961, 26, 6. (c) Cotter, R. J.; Sauers, C. K.; Whelan, J. M. J. Org. Chem. 1961, 26, 10. (d) Curtin, D. Y.; Miller, L. L. Tetrahedron Lett. 1965, 1869. (e) Hedaya, E.; Hinman, R. L.; Theodoropulos, S. J. Org. Chem. 1966, 31, 1311. (f) Hedaya, E.; Hinman, R. L.; Theodoropulos, S. J. Org. Chem. 1966, 31, 1317. (g) Ernst, M. L.; Schmir, G. L. J. Am.Chem. Soc. 1966, 88, 5001. (h) Curtin, D. Y.; Miller, L. L. J. Am. Chem. Soc. 1967, 89, 637. (i) Barratt, M. D.; Davies, A. P.; Evans, M. T. A. Eur. J. Biochem. 1971, 24, 280. (j) Anderson, N. H.; Ollis, W. D.; Thorpe, J. E.; Ward, A. D. J. Chem. Soc., Perkin Trans. 1 1975, 825. (k) Boyd, G. V.; Monteil, R. L. J. Chem. Soc., Perkin Trans. 1 1978, 1338. (l) 
Mazurkiewicz, R. Wiad. Chem. 1987, 41, 755. (m) Nielsen, O.; Buchardt, O. Synthesis 1991, 819. (n) Ezzell, S. A.; Hansen, R. G.; Anderson, G. J. PCT Int.Appl. WO 9720832 A1, 1997, 51; Chem. Abstr. 1997, 127, 109325. (o) Fruk, L.; Graham, D. Heterocycles 2003, 60, 2305. (p) Conley, N. R.; Hung, R. J.; Willson, C. G. J. Org. Chem. 2005, 70, 4553 and references cited therein 1a-p.

2. (a) Searle, N. E. U.S. Patent 2,444,536, 1948; Chem. Abstr. 1948, 42, 7340. (b) Mehta, N. B.; Phillips, A. P.; Lui, F. F.; Brooks, R. E. J. Org. Chem. 1960, 25, 1012. (c) Braish, T. F.; Fox, D. E. Synlett 1992, 979. (d) Reddy, P. Y.; Kondo, S.; Toru, T.; Ueno, Y. J. Org. Chem. 1997, 62, 2652. (e) Le, Z.-G.; Chen, Z.-C.; Hu, Y.; Zheng, Q.-G. Synthesis 2004, 995 and references cited therein $2 \mathrm{a}-\mathrm{e}$.

3. Klimenkovs, I.; Zicmanis, A.; Uzulina, I.; Graillat, C.; Guyot,A.J. Dispersion Sci. Technol. 2004, 25, 119.

4. Marasco, J.-P.; Garapon, J.; Sillion, B. Polym. Bull. 1995, 35, 285.13. (a) Mochizuki, A.; Teranishi, T.; Ueda, M. Polym. Prepr. 1994, 35, 371. (b) Kasai, T. Jpn. Kokai Tokkyo Koho JP A2 7,1994; Chem. Abstr. 1995, 122, 163013.

5. (a) Mochizuki, A.; Teranishi, T.; Ueda, M. Polym. Prepr.1994, 35, 371.

6. Ikeda, K.; Yamashita, W.; Tamai, S. Eur. Pat. Appl. EP 846714 A1 36, 1998; Chem. Abstr. $1998,129,68137$.

7. (a) Capraro, H. G.; Winkler, T.; Martin, P. Helv. Chim. Acta 1983, 66, 362. (b) Capraro, H. G.; Rhis, G.; Martin, P. Helv. Chim. Acta 1983, 66, 633. (c) Barba, V.; Hernandez, C.; RojasLima, S.; Fartin, N.; Norberto, S. R. Can. J. Chem. 1999, 77, 2025.

8. Domeier, L. A.; Clark, E. M. Eur. Pat. Appl. Ep 277013 A1 6,1988; Chem. Abstr. 1989, 110, 76676. 
9. Nagarathinam, R.; Viswanathan, S. Polym. Bull. 1986, 16, 147.

10. Kirino, O.; Rubin, B.; Casida, J. E. Agric. Biol. Chem. 1985, 49, 267.

11. (a) Awad, W. I.; Wasfi, A. S.; Ewad, M. J. S. J. Iraqi Chem.Soc. 1977, 2, 5. (b) Harris, F. W.;

Karnavas, A. J.;Cucuras, C. N.; Das, S. Polym. Prepr. 1985, 26, 287. (c) Oishi, T.; Fujimoto, M.;

Yoshimoto, N.; Kimura, T. Polym. J. 1989, 21, 655.

12. Kasai, T. Jpn. Kokai Tokkyo Koho JP A2 7,1994; Chem. Abstr. 1995, 122, 163013.

13 (a) Kozyrev, A. N.; Zheng, G.; Lazarou, E.; Dougherty, T. J.; Smith, K. M.; Pandey, R. K.

Tetrahedron Lett. 1997, 38, 3335. (b) Pandey, R. K.; Kozyrev, A. N.; Dougherty, T. J. PCT Int. Appl. WO 9732885 A1 47, 1997; Chem. Abstr. 1997, 127, 247962.

14. Theodoropulos, S. U.S. US 4789742 A6 7, 1988; Chem. Abstr. 1989, 111, 97063.

15. Nagata, T.; Tamaoki, A.; Kajimoto, N.; Wada, M. Jpn. Kokai Tokkyo Koho JP 61022074 A24, 1986; Chem. Abstr. 1986, 105, 24175.

16. (a) Baumann, M. Eur. Pat. Appl. EP 38303 A2 16, 1981; Chem. Abstr. 1982, 96, 52172. (b) Raetzsch, M.; Krahl, K. Acta Polym. 1984, 36, 91. (c) Kurimoto, I.; Yoshimura, M.; Inoue, K. Yamaguchi, T. Jpn. Kokai Tokkyo Koho JP01056670 A2 8, 1989; Chem. Abstr. 1989, 111, 175922. (d)Kurita, K.; Suzuki, Y.; Enari, T.; Kikuchi, M.; Nishimura, S.; Ishii, S. J. Polym. Sci., Part A: Polym. Chem. 1994, 32, 393. (e) Corrie, J. E. T.; Moore, M. H.; Wilson, G. D. J. Chem. Soc., Perkin Trans. 1 1996, 777.

17. Aziz, T.; Shubber, A. Iraqi J. Sci. 1981, 22, 340.

18. Roth, M. Ger. Offen. DE 2705186 18, 1977; Chem. Abstr. 1977, 87, 167864.

19. Ikeda, K.; Yamashita, W.; Tamai, S. U.S. US 5892061 A6 24, 1999; Chem. Abstr. 1999, 130, 281980.

20. Kishan P. H.; Santosh B. M.; Narshimha P. A, Tetrahedron, 2006, 62, 937-942. 
21. De, P, Gondi, S. R.; Sumerlin, B.S. Biomacromolecules, 2008, 9(3), 1064-1070.

22. Paquette, L. A.; Wittenbrook, L.S. Chem. Commun,1966, (14), 471-473.

23. Ezzell, S.A.; Hansen, R.G.; Anderson, G.J. PCT Int. Appl. 1997, 51 pp. Application: WO 95-US15885 19951205. Priority: . CAN 127:109325 AN 1997:479359

24, Takase, I; Taniguchi, T; Aida, H. Kobunshi Ronbunshu, 1977, 34(12), 857-865.

25. (a) Ganin, E. V.; Zhurnal Organicheskoi Khimii 1985, V21(9), 1935-1941. (b) Brown, R.

F. C.; Coulston, K.J.; Eastwood, F.W. Aust.J.Chem. 1994, 47(1), 47-59.

26. (a) Ganin, E. V.; Makarov, V. F.; Luk'yanenko, N. G.; Kotlyar, S. A. Khimiya Geterotsiklicheskikh Soedinenii, 1987, (4), 536-539. (b) Kobunshi Ronbunshu (1992), 49(6), 513519. 